\title{
Asiakaspalautetieto ja sen hyödyntäminen sairaalan johtamisessa
}

\author{
Ritva Kosklin, Johanna Lammintakanen \& Tuula Kivinen
}

\section{ABSTRACT \\ Customer feedback information and its utilization in hospital management}

The aim of this study is to increase our comprehension of how customer feedback information is managed in the context of hospital management. The study is qualitative and built on case-study. Material were collected of two focus groups and it involved 13 leaders from different hospital management levels. Customer feedback information is collected simultaneously in several ways; oral feedback is not collected systematically. Customers provide feedback on service, care, friendliness and general hospital functioning. Customer feedback information is processed primarily by the unit attended by the customer. Physicians and nurses have a different role in customer feedback information processing. Hospital customer information processing is declarative and there is no uniform view on how to transfer customer feedback information between management levels. It is difficult to form a common conception of customer feedback information on the organizational level of this hospital.

Keywords: Customer feedback information, knowledge management, healthcare, hospital

\section{JOHDANTO}

Artikkeli kohdistuu asiakaspalautetiedon hyödyntämiseen julkisen sairaalan johtamisessa. Terveydenhuollon kehityksen myötä palveluja, tutkimuksia ja hoitoa tarvitsevan yksilön asema on muuttunut perinteisestä potilaasta osallistuvaksi ja valintoja tekeväksi asiakkaaksi (Deber ym. 2005, 349-350; Tritter 2009, 210-226; Hakulinen ym. 2012, 19-35; Kalliomaa-Puha 2015, 133-153). Asiakkaiden näkemysten merkitys on tunnistettu palvelujen suunnittelussa, kehittämisessä ja johtamisessa (White 2012, 84-88). Potilaan nimeäminen asiakkaaksi pitää sisällään ajatuksen yksilön oikeuksista, osallisuudesta, mahdollisuudesta esittää toivomuksia ja valittaa huonosta kokemuksesta. Potilaiden lisäksi sairaalan asiakkaita ovat kunnat, kuntayhtymät, toiset organisaatiot ja niiden sisällä toimivat yksiköt. (Valkama 2009, 27, 29-30.) Asiakkaina voivat olla myös terveydenhuollon ammattihenkilöt, kuten lääkärit ja omaiset (Mazurenko ym. 2016). Tässä tutkimuksessa asiakkaalla tarkoitetaan sairaalassa palveluja, tutkimuksia ja hoitoa tarvitsevia henkilöitä.

Terveydenhuollon asiakkaan osallistumisen ja valinnanvapauden perusta on luotu Suomessa lainsäädännössä (Sihvo ym. 2018, 13). Asiakkaan roolia on vahvistettu kehittämällä määrätietoisesti asiakaslähtöisiä palveluja esimerkiksi erilaisilla kehittämishankkeilla (Sosiaali- ja terveysministeriö 2010, 11-12; Valtioneuvoston kanslia 2015). Asiakaslähtöisyys on moniulotteinen käsite, joka aikaisemmissa tutkimuksissa on määritelty asiakkaan lähtökohtien, arvojen ja tarpeiden huomioimiseksi, mahdollisuudeksi osallistua omaa hoitoa koskeviin päätöksiin, selkeäksi kommunikoinniksi ja pääsyksi oikea-aikaisesti tarvittavaan hoitoon. Asiakaslähtöisyys on yhteydessä hoidon laatuun, turvallisuuteen ja vaikuttavuuteen. (Epstein ym. 2010, 1489-1495; Santana ym. 2018, 435-437.) Tämä kattaa myös asiakkaan odotusten, tarpeiden ja hoitoon liittyvien toivomusten kysymisen sekä asiakkaan antaman arvion siitä, miten hyvin organisaatio on tehtävässään onnistunut (Terveyden ja hyvinvoinnin laitos 2011).

Asiakaspalautetieto on osa asiakkaiden, terveydenhuollon ammattihenkilöiden ja johtajien välistä vuorovaikutusta tuottaen siten tärkeää tietoa asiakaslähtöisten palvelujen johtamiseen ja kehittämiseen (García-Murillo \& Annabi 2002, 875-884). Aikaisemmissa tutkimuksissa asiakas- 
palautetietoa on kuvattu asiakassuhteessa tuotettavaksi, asiakkailta itseltään saaduksi tiedoksi, jota organisaatio voi hyödyntää toiminnassaan, sen kehittämisessä, suunnittelussa ja johtamisessa (García-Murillo \& Annabi 2002, 875-884; Chen \& Popovich 2003, 685-686; Chen \& Su 2006, 605-607). Puutteellisen tiedonhallinnan vuoksi tietojärjestelmiin koottu asiakaspalautetieto jää sairaalan johtamisessa huomioimatta, eikä asiakaslähtöisyys korostu johtamisessa (Virtanen ym. 2011, 50-52). Asiakaspalautetieto sisältää asiakkaiden näkemyksen palvelusta, hoidosta, henkilökunnan ammatillisuudesta, ammattitaidosta, vuorovaikutuksesta ja sairaalan toiminnasta (Woodside ym. 1989; RamsaranFowdar 2005). Hyväksi koettu palvelun laatu vahvistaa asiakkaiden myönteistä suhtautumista tarjottavaan palveluun (Naidu 2009, 377). Asiakaspalautetieto on liitetty terveydenhuollossa palvelujen laadun arviointiin (Butler ym. 1996). Sitä on tutkittu esimerkiksi lääkäreiden toiminnan laadun (Kumah 2018), hoitotyön laadun (Johansson ym. 2002), asiakkaiden tekemien valitusten (Harrison ym. 2016) ja uusien terveydenhuollon teknisten ratkaisujen käyttöön ottamisen näkökulmista (Mair \& Whitten 2000).

Tämä tutkimus linkittyy julkisen terveydenhuollon johtamista koskevaan keskusteluun, jossa johtamisessa tarvittavan tiedon lisäksi on eri tavoin nostettu esille organisaation sisäisen tiedonhallinnan tarkastelun tarve (Kivinen 2008; Mertala, 2011; Jylhä 2017). Osallistumme tähän keskusteluun tarkastelemalla asiakaspalautetiedon johtamista ja siihen liittyvää koko tiedonhallinnan prosessia sairaalan eri tasoilla toimivien johtajien kuvaamana. Asiakaspalautetiedon hallinta tarjoaa lähtökohdan johtamiselle, jossa tavoitellaan aktiivista asetettuihin tehtäviin ja tavoitteisiin tähtäävää toimintaa. Toiminnan liikkeelle panevana voimana voivat olla strategiset tavoitteet, organisaation vallitseva tilanne, erilaiset toimijat tai asiakkaiden tarpeet. (Syväjärvi \& Pietiläinen 2016, 13.) Tarkennetut tutkimuskysymykset ovat: 1) Millä tavalla asiakaspalautetietoa sairaalassa saadaan ja minkälaista saatu tieto on sisällöllisesti? 2) Miten asiakaspalautetietoa käsitellään ja jaetaan sairaalassa johtamisen eri tasoilla? 3) Miten asiakaspalautetietoa hyödynnetään johtamisessa? 4) Minkälaista yhteistä organisatorista asiakaspalautetietoa sairaalassa muodostuu?

\section{TEOREETTISET LÄHTÖKOHDAT}

Artikkelissa jäsennetään asiakaspalautetiedon hallintaa Choon mallin $(1996,2002)$ ja uuden organisatorisen tiedon muodostamista Nonakan ja Takeuchin teorian (1995) mukaisesti sairaalan johtamisen kontekstissa. Valitut lähtökohdat soveltuvat organisatorisen tiedonhallinnan tarkasteluun ja kuvaavat tiedon hyödyntämistä organisaation johtamisessa. Käsitys tiedosta on molempien edellä mainittujen lähtökohtien perusta. Suomen kielen tieto-käsitettä englannin kielessä vastaavat data, information ja knowledge. Tutkimuskirjallisuudessa nämä käsitteet ja niihin sisältyvät tiedon tasot määritellään ja erotetaan toisistaan. (Bouthillier \& Shearer 2002; Kivinen 2008.) Alimmalla tiedon tasolla on data, joka sisältää yksittäisiä merkkejä ja signaaleja. Sitä kerätään sairaalassa erilaisiin tietojärjestelmiin ja siitä muodostetaan informaatiota käsittelemällä, analysoimalla ja liittämällä se tiettyyn asiayhteyteen. Informaatio muuttuu organisaatiossa tiedoksi, kun ihmiset muokkaavat sitä, tekevät johtopäätöksiä, liittävät informaation muuhun tietoon ja keskustelevat siitä. Tätä kautta tietämys organisaatiossa lisääntyy. Organisaatiossa tieto linkittyy ihmisten asenteisiin, arvoihin ja kokemuksiin, minkä seurauksena tieto saa dynaamisen osaamista kuvaavan luonteen. (Nonaka \& Takeuchi 1995, 57-59; Davenport \& Prusak 1998, 5-7; Kivinen 2008, 47.)

Nonaka ja Takeuchi (1995) jakavat organisatorisen tiedon hiljaiseen (tacit) ja eksplisiittiseen (explicit) tietoon, jonka juuret ovat Polanyin 1940-luvulla esittämässä tietoteoriassa. Eksplisiittinen tieto on määriteltyä, konkreettista ja muodollista, ja sitä voidaan helposti prosessoida ja siirtää (Nonaka \& Takeuchi 1995, 5759). Tällaista tietoa sairaalassa ovat esimerkiksi toimintaa ohjaavat säännöt ja ohjeet. Hiljainen tieto on henkilökohtaista ja kokemuksellista, ja sitä on vaikea ilmaista ja siirtää henkilöltä toiselle. Nonakan ja Takeuchin (1995) mukaan hiljainen tieto jakaantuu kognitiiviseen ja tekniseen ulottuvuuteen. Kognitiiviseen ulottuvuuteen sisältyvät arvot, ideaalit, mallit ja skeemat. Tekniseen ulottuvuuteen sisältyvät puolestaan ammattitaidon ja osaamisen erilaiset osa-alueet.

Choon $(1996,2002)$ esittämässä tiedonhallinnan mallissa (Information management model) organisaation tiedonhallinta rakentuu erilaisten 


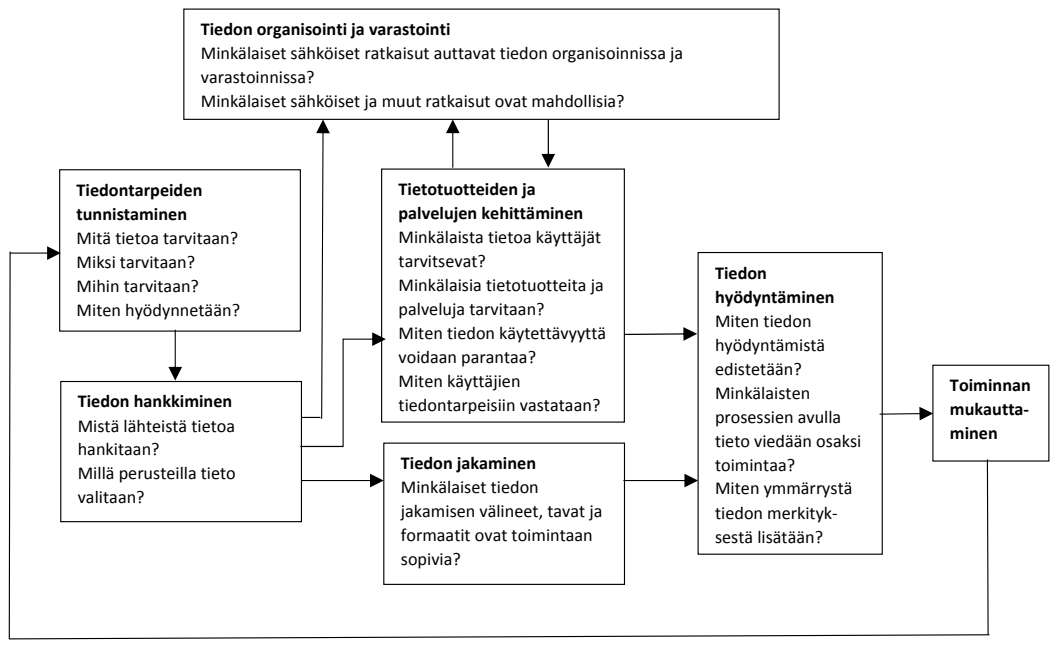

Kuvio 1. Tiedonhallinnan malli (mukaillen Choo 1996, 2002 ja Valkonen ym. 2018).

Kuvio 1. Tiedonhallinnan malli (mukaillen Choo 1996, 2002 ja Valkonen ym. 2018).

organisaation oppimista tukevien prosessien johtamisesta. Mallissa tiedonhallintaa kuvataan jatkuvana syklinä, jossa voidaan erottaa kuusi erillistä, mutta kiinteästi toisiinsa liittyvää toimintoa. Näitä ovat tiedontarpeiden tunnistaminen, tiedon hankkiminen, tiedon organisointi ja varastointi, tietotuotteiden ja palvelujen kehittäminen, tiedon jakaminen ja hyödyntäminen. Tiedonhallinnan malli sisältää ajatuksen organisaation toiminnan muuttamisesta ja mukauttamisesta kootun tiedon perusteella. Kuviossa yksi on kuvattu tiedonhallinnan malli ja sen eri vaiheisiin liittyviä keskeisiä kysymyksiä.

Choon (1996) näkemystä mukaillen asiakaspalautetiedon hallinnan prosessi käynnistyy sairaalassa tarpeesta hankkia asiakaspalautetietoa toiminnan johtamisen ja kehittämisen tueksi (ks. myös Valkonen ym. 2018). Asiakaspalautetiedon merkitys on tunnistettu tiedonhallinnan kokonaisuudessa (García-Murillo \& Annabi 2002, 875) ja sen keräämistä on pyritty tehostamaan sairaaloissa. Asiakaspalautetietoa voidaan kerätä ennen palvelujen käyttämistä, palvelu- ja hoitoprosessien aikana sekä palvelujen käyttämisen jälkeen. Jatkuvaa asiakaspalautetta sairaaloissa on koottu palautelomakkeiden avulla. Tietojärjestelmien kehittyessä palautelomakkeilla koottu asiakaspalautetieto on tallennettu yhteiseen tietokantaan. Vähitellen asiakkaille on tullut mahdollisuus antaa palautetta myös verkkokyselyjen avulla organisaation kotisivuilla tai vastaamalla tekstiviestiin (Terveyden ja hyvinvoinnin laitos 2011). Muistutukset ovat sairaalan sisäinen asiakaspalautekeino. Asiakkaat voivat tehdä hoitoaan koskevan kantelun organisaation ulkopuolelle aluehallintovirastoon (Palomäki \& Vanhala 2016, 46). Potilasasiamiesten tehtävänä sairaalassa on neuvoa ja tukea asiakkaita. Heidän kauttaan saadaan asiakkaiden yhteydenottojen perusteella koottua asiakaspalautetietoa.

Terveyden ja hyvinvoinnin laitoksen toimeksiannosta sairaaloissa on toteutettu valtakunnallisia asiakaspalautekyselyitä. Nykyisin suomalaisista sairaaloista ei pystytä kokoamaan jatkuvaa valtakunnallisesti vertailukelpoista asiakaspalautetietoa, koska organisaatioiden tiedonkeruutavoissa ja mittareissa on eroja. (Terveyden ja hyvinvoinnin laitos 2011; Peränen \& Sainio 2018.) Tiedonhallintaan liittyvät muutostarpeet kohdistuvat yhtenäisen asiakaspalautetiedon tuottamiseen ja parempaan hyödyntämiseen toiminnassa (Sosiaali- ja terveysministeriö 2014, 8).

Saadut kirjalliset palautteet ovat vain osa kaikesta palvelun ja hoidon yhteydessä annetusta 
asiakaspalautteesta (Tritter 2009). Valtaosa sairaalan asiakaspalautteesta annetaan suullisesti vastaanotoilla ja hoitotilanteissa. Parhaimmillaan asiakkaan ja ammattilaisen kahdenkeskisessä kohtaamisessa organisaation osaamista siirtyy asiakkaalle ja vastaavasti organisaatio saa asiakkaalta tietoa, oppii ja voi kehittää sen avulla toimintaansa (García-Murillo \& Annabi 2002, 875-884; Kaseva 2011, 41-45). Asiakasraatitoiminnalla on kansainvälisesti pitkä perinne (Angstman ym. 2009, 328-332; Taloney \& Flores 2013, 247-253), ja sen avulla on haluttu edistää asiakkaiden ja terveydenhuollon ammattihenkilöiden vuorovaikutusta sekä edustuksellisen asiakaspalautetiedon keräämistä. Edustuksellista asiakaspalautetietoa saadaan myös kokemusasiantuntijoiden välityksellä (Rissanen \& Puumalainen 2016, 1-7).

Tiedon organisoinnin ja varastoinnin vaiheessa ratkaistaan tiedon säilyttämiseen, tuotettavan tiedon rakenteeseen ja saatavuuteen liittyviä kysymyksiä. Tiedon jakamisen vaiheessa tuotettua tietoa jaetaan käyttäjille erilaisten tiedonjakelukanavien kautta. (Choo 1996, 2002.) Tutkimusten mukaan asiakaspalautetietoa kootaan sairaalassa useista eri lähteistä samanaikaisesti, mutta sitä ei analysoida ja prosessoida riittävästi, jotta sitä voitaisiin hyödyntää laajasti johtamisessa ja kehittämisessä (Chen \& Popovich 2003, 672-688; Myllärniemi ym. 2012, 61). Tietovarannoissa olevasta tiedosta rakennetaan käyttäjien tiedontarpeita vastaavia tuotteita ja palveluja. Sairaalan tietojärjestelmät eivät kuitenkaan tue riittävästi asiakaspalautetiedon käsittelyä ja erilaisten toimijoiden keskinäistä yhteistyötä. (Chen \& Popovich 2003, 672-688; Myllärniemi ym. 2012, 61.) Tutkimusten mukaan tiedon jakamista estävät professioiden erilaiset näkemykset ja ammattikulttuurit (Kivinen 2008; Kim ym. 2012). Eri ammattiryhmillä on taipumus jakaa tietoa pääasiassa vain oman ammattiryhmänsä jäsenille (Currie \& White 2012, 1353; Tasseli 2014, 619-660). Tiedon jakamisen edistämiseksi ja keskinäisen vertailun kehittämiseksi julkisissa sairaaloissa tavoitellaan yhtenäisten asiakaspalautemittareiden käyttöön ottamista (Peränen \& Sainio 2018).

Choon $(1996,2002)$ tiedonhallinnan mallin keskiössä on eksplisiittisen tiedon hallinta. Valtaosa asiakkaiden antamasta palautteesta on suullista, jolloin asiakkaalta saatu palaute jää helposti yksittäisen ammattihenkilön henkilökohtaiseksi hiljaiseksi tiedoksi (Virtanen ym. 2011, 48-53). Suullisesti saadun asiakaspalautteen hyödyntäminen organisaatiossa edellyttää sen muuttamista tallennettavaan muotoon ja yhdistämistä muulla tavoin kerättyyn asiakaspalautetietoon (Nonaka \& Takeuchi 1995). Tiedon luomisen prosessimalli (SECI-malli) kuvaa uuden tiedon syntymistä organisaatiossa neljän erilaisen vaiheen kautta, joita ovat sosialisaatio, ulkoistaminen, yhdistäminen ja sisäistäminen. Organisaation yhteinen tieto muodostuu siirtymällä spiraalimaisesti tasolta toiselle läpi koko organisaation. Organisatorisen tiedon muodostaminen edellyttää toimijoiden välistä vuorovaikusta, luottamusta, yhteistyötä ja sitoutumista yhteisesti sovittuihin toimintamalleihin. (Nonaka \& Takeuchi 1995, 59-61; Kakabadse ym. 2001, 139-140; Kivinen 2008.) Sairaalassa asiakaspalautetiedon käsittely on osa moniammatillista yhteistyötä, jossa jokainen sovittaa omaa työtään toisten työhön ja samalla osaksi sovittuja tavoitteita. Asiakaspalautetiedon merkityksellisyys muodostuu siitä, että sitä voidaan hyödyntää aidosti organisaation toiminnassa (Bouthillier \& Shearer 2002) ja sen avulla kyetään luomaan uutta tietoa, jolloin organisaatio oppii ja pystyy kehittämään jatkuvasti toimintaansa (Nonaka \& Takeuchi 1995, 59-61; Kakabadse ym. 2001, 139-140; Arantola 2006, 53-56; Kivinen 2008).

Organisatorisen tiedon muodostaminen edellyttää erilaisten ryhmien ja verkostojen tavoitteellista ja tietoista rakentamista sekä riittävän monipuolista ja runsasta asiakaspalautetietoperustaa. Sairaalassa on kuitenkin tunnistettu negatiivisen palautteen antamiseen ja vastaanottamiseen liittyviä jännitteitä. Kritiikin esittämistä annetusta hoidosta ei ole pidetty asiakkaan asemassa olevalle sopivana. (Mulcahy 2003.) Asiakkaan näkökulmasta negatiivisen palautteen antamisen esteenä on riippuvuus terveydenhuollon palveluista ja halu pitää yllä positiivista suhdetta terveydenhuollon ammattihenkilöihin (Edvards ym. 2004, 159). Asiakkaan antamaan palautteeseen vaikuttavat myös terveydenhuollon ulkopuoliset asiat, kuten asiakkaan ikä, sosiaalinen tausta, sairaus ja odotukset hoidosta (Bleich ym. 2009, 271-278).

Johtamisen yhtenä tavoitteena on uuden organisatorisen tiedon soveltaminen käytäntöön. Sairaalan johtamisessa tietoa käytetään suun- 
nitteluun, päätöksentekoon, toimeenpanoon, seurantaan ja arviointiin. Sisällöllisesti johtamisessa käytettävä tieto muodostuu esimerkiksi taloutta, henkilöstöä, suoritteita ja asiakkaita koskevasta tiedosta. Vaikka asiakaspalautetietoa kerätään sairaalassa runsaasti, sen käsittely tapahtuu irrallisena muusta johtamisessa käsiteltävästä tiedosta. (Saranto \& Kuusisto-Niemi 2011, 215-235.) Organisaatiossa toimivilla johtajilla on kuitenkin keskeinen rooli tiedon käsittelyn kehittämisessä ja luottamuksellisen tiedon jakamisen ilmapiirin muodostamisessa (Kim ym. 2012). Nonakan ja Takeuchin $(1995,15)$ näkemyksen mukaan keskijohdon tehtävänä on sovittaa yhteen lähijohdon välittämä toimintaa koskeva tieto ja ylimmän johdon yhteisen tiedon pohjalta esittämä tulevaisuuden visio. Keskijohdolla on lisäksi merkittävä rooli uuden tiedon jakamisessa horisontaalisesti ja vertikaalisesti organisaatiossa. Tiedonhallinnan mallin avulla sairaalaorganisaatiossa voidaan edistää strategista ja operatiivista tietoon perustuvaa toimintaa (Pirttimäki 2007, 54). Haasteena on julkisten sairaaloiden toiminnan järjestäminen yhä organisaatio- eikä asiakaslähtöisesti.

\section{TUTKIMUSAINEISTO JA ANALYYSI- MENETELMÄT}

Tutkimus on luonteeltaan kvalitatiivinen (Hirsjärvi ym. 2008, 135-161), ja tutkimuksessa sovelletaan tapaustutkimuksen (case-study) lähestymistapaa, jolle on ominaista tutkittavien tapausten ainutkertaisuus. Tutkimuskohteena voivat olla sekä organisaatiot että yksilöt. Tapaustutkimuksen periaatteen mukaisesti tavoitteena on pyrkiä ymmärtämään syvällisesti tutkimuskohteena olevaa tapausta tai tapauksia omassa ainutkertaisessa ympäristössään. (Easton 1992.) Tapaustutkimus kytkeytyy aikaisempaan teoriapohjaan, joka muodostaa perustan aineiston analyysin ja johtopäätösten tekemiselle. Tässä tutkimuksessa teoriapohjan muodostavat tiedonhallinnan ja organisatorisen uuden tiedon muodostamisen mallit (Nonaka \& Takeuchi 1995; Choo 1996; 2002).

Tutkimus toteutettiin yhdessä suuressa suomalaisessa julkisessa sairaalassa kesäkuussa 2017. Sairaalassa on ollut pitkään käytössä sähköinen asiakaspalautetietojärjestelmä, jonne kirjallisesti saatu asiakaspalautetieto kootaan. Asiakaspalau- tetiedon keräämistä, käsittelyä ja jakamista on ohjeistettu tutkimuksen kohteena olevassa sairaalassa, ja organisaation eri tasoilla toimivien johtajien vastuita asiakaspalautetiedon hallinnassa on määritelty. Tutkimusta varten haastateltiin yhteensä 13 henkilöä kahdessa fokusryhmässä (Krueger \& Casey 2009). Ensimmäiseen fokusryhmään lähijohdosta osallistui kolme henkilöä, keskijohdosta kaksi henkilöä ja ylimmästä johdosta kaksi henkilöä. Toiseen fokusryhmään lähijohdosta osallistui kolme henkilöä ja keskijohdosta kolme henkilöä. Tutkimukseen osallistuneet henkilöt edustivat sairaalan erilaisia toiminta-alueita, joissa kohdataan erilaisia asiakkaita. Kaikki tutkimukseen osallistujat olivat naisia. Osallistujilla oli ammatillisen koulutuksen lisäksi vaihtelevasti erilaista johtamiskoulutusta. Kokemus nykyisestä johtamistehtävästä vaihteli $1-2$ vuodesta yli 10 vuoteen.

Fokusryhmähaastatteluissa oli mukana avustaja, joka teki havaintoja ja muistiinpanoja haastattelujen kulusta ja laati yhteenvedon fokusryhmissä käydyistä keskusteluista. Haastattelut toteutettiin seuraavien tutkimuskysymyksistä johdettujen haastatteluteemojen mukaisesti: 1) sairaalassa saatava asiakaspalautetieto, 2) asiakaspalautetiedon käsittely sairaalassa, 3) asiakaspalautetiedon siirtyminen johtamistasojen välillä, 4) asiakaspalautetiedon hyödyntäminen johtamisessa ja 5) kokonaiskuva asiakaspalautetiedosta ja sen hyödyntämisestä kehittämisessä. Haastattelutilanteet olivat rauhallisia ja tunnelma haastattelutilanteissa oli rakentava. Kumpikin fokusryhmähaastattelu kesti noin puolitoista tuntia. Haastattelut nauhoitettiin, tallennettiin ja purettiin sanatarkasti kirjoitettuun muotoon. Litteroitua tekstiä haastatteluista kertyi yhteensä 65 sivua A4-kokoista arkkia (fonttikoko 12 ja riviväli $1,5)$.

Haastatteluaineistot analysoitiin aineistolähtöisellä sisällönanalyysillä (Latvala \& VanhanenNuutinen 2001). Analyysiprosessissa edettiin haastatteluteemoittain ja jokaisesta teemaalueesta haettiin tutkimuskysymysten kannalta olennaiset alkuperäisilmaisut. Seuraavassa vaiheessa alkuperäisilmaisut pelkistettiin. Aineiston ryhmittelyvaiheessa samankaltaiset pelkistetyt ilmaisut jaoteltiin omiksi kokonaisuuksikseen haastatteluteemoittain ja niistä muodostetiin alaluokkia, joita tarkennettiin analyysin edetessä. Tämän jälkeen alaluokkia verrattiin 
Taulukko 1. Esimerkki aineistolähtöisestä sisällönanalyysistä.

\begin{tabular}{|c|c|c|c|}
\hline Alkuperäinen ilmaisu ja pelkistys & Alaluokka & Yläluokka & Kokoava käsite \\
\hline $\begin{array}{l}\text { Tää osastokokous, että käsitellään osastokokouksissa. } \\
\text { Se on siis osastonhoitajan pitämä kokous } \\
\text { hoitotyöntekijöille niin, että harvoinpa sinne lääkäri } \\
\text { tulee. } \\
\text { Asiakaspalautetta käsitellään osastokokouksissa, joka } \\
\text { on osastonhoitajan hoitohenkilökunnalle pitämä } \\
\text { kokous, jonne lääkärit tulevat harvoin. } \\
\text { Käsitellään osastoilla kokouksissa... osastolla } \\
\text { osastokokous on kyllä sitä osastonhoitajan pitämää, } \\
\text { hoitajien kanssa pitämää kokousta. Kyllä sinne } \\
\text { lääkäritkin tulla saa, mutta harvoin heitä näkyy. } \\
\text { Asiakaspalautteet käsitellään osastokokouksissa, joka } \\
\text { on osastonhoitajan hoitohenkilökunnan kanssa pitämä } \\
\text { kokous. Lääkäritkin voivat osallistua, mutta heitä } \\
\text { näkyy harvoin kokouksissa. }\end{array}$ & $\begin{array}{l}\text { Asiakaspalautteen } \\
\text { käsittely } \\
\text { osastonhoitajan } \\
\text { pitämissä } \\
\text { osastokokouksissa } \\
\text { hoitohenkilökunnan } \\
\text { kesken }\end{array}$ & $\begin{array}{l}\text { Asiakaspalautteen } \\
\text { käsittely } \\
\text { osastokokouksissa }\end{array}$ & $\begin{array}{l}\text { Asiakaspalautteen } \\
\text { käsittely } \\
\text { työyksiköissä }\end{array}$ \\
\hline $\begin{array}{l}\text { Meillä on ihan sama juttu, että käydään (keskustelu) } \\
\text { siellä niinkun yksikössä heti ihan niin nopeasti, kun vaan } \\
\text { pystytään nämä ja sit siinä kohtaa kyllä mietitään, että } \\
\text { onko nyt jotain, mitä voimme tälle asialle tehdä. } \\
\text { Työyksikössä asiakaspalautteesta käydään keskustelu } \\
\text { niin nopeasti, kun pystytään ja samalla mietitään, } \\
\text { onko jotakin mitä asialle voidaan tehdä. } \\
\text { Eri yksiköissä ... se (palautteen käsittely) onnistuu mun } \\
\text { mielestä tosi helposti. } \\
\text { Asiakaspalautteen käsittely onnistuu mielestäni } \\
\text { työyksikössä helposti. }\end{array}$ & $\begin{array}{l}\text { Asiakaspalautteen } \\
\text { käsittelyn helppous } \\
\text { ja nopeus } \\
\text { työyksiköissä }\end{array}$ & $\begin{array}{l}\text { Asiakaspalautteen } \\
\text { käsittelyn sujuvuus }\end{array}$ & \\
\hline $\begin{array}{l}\text { Jotenkin aattelisin, että ne tiimit siellä toiminnan } \\
\text { tasolla, niin niitten pitäis sitten parhaimmillaan } \\
\text { pystyä yhdessä käymään läpi sitä, että mitä } \\
\text { palautetta heidän potilaat on antaneet. } \\
\text { Ajattelen, että niiden tiimien siellä toiminnan tasolla } \\
\text { pitäisi parhaimmillaan pystyä yhdessä käymään } \\
\text { lävitse asiakkaiden antamaa palautetta. }\end{array}$ & $\begin{array}{l}\text { Asiakaspalautteen } \\
\text { käsittely erilaisissa } \\
\text { hoitotiimeissä }\end{array}$ & $\begin{array}{l}\text { Asiakaspalautteen } \\
\text { käsittely tiimeissä }\end{array}$ & \\
\hline $\begin{array}{l}\text { Jos se on joku tällainen pieni juttu niin se on niinkun } \\
\text { osastonhoitajan ja mun välinen juttu, kun jutellaan siitä. } \\
\text { Jos kyseessä on pieni asiakaspalauteasia, niin se on } \\
\text { lähijohtajien välinen asia, josta keskustellaan yhdessä. }\end{array}$ & $\begin{array}{l}\text { Lähijohtajien } \\
\text { keskinäinen } \\
\text { keskustelu } \\
\text { asiakaspalautteesta }\end{array}$ & $\begin{array}{l}\text { Keskustelu } \\
\text { asiakaspalautteesta } \\
\text { lähijohdossa }\end{array}$ & \\
\hline
\end{tabular}

keskenään, sisällöltään samanlaiset asiat yhdistetiin ja abstrahoitiin niille yhteinen yläluokka. Lopuksi muodostettuja yläluokkia verrattiin keskenään ja haettiin niille yhteinen kokoava yläkäsite. (Tuomi \& Sarajärvi 2009, 108-113.) Esimerkki aineistolähtöisestä sisällönanalyysistä on esitetty taulukossa yksi.

\section{TULOKSET}

\section{Sairaalassa saatava asiakaspalautetieto}

Fokusryhmähaastatteluihin osallistuneiden johtajien näkemyksen mukaan asiakkailta saadaan palautetietoa monella eri tavalla samanaikaisesti, mutta saatujen tietojen yhdistäminen ei ole sairaalassa ongelmatonta. Suullista asiakaspalautetietoa saadaan monissa erilaisissa asiakaskontakteissa, kuten ilmoittautumisen yhteydessä, vastaanotoilla, toteutettaessa hoitoja ja keskus- 
teltaessa asiakkaan sekä hänen omaistensa kanssa. Suullisen asiakaspalautetiedon saamiseen vastaanotolla ja hoitotilanteessa vaikuttaa henkilökunnan toiminnasta asiakkaille välittyvä rauhallisuus tai kiire. Osa johtajista arvioi, että asiakkaat eivät uskalla antaa negatiivista palautetta, koska pelkäävät sen vaikuttavan toteutettavaan hoitoon. Pyrkiessään selvittämään omaan hoitoonsa liittyviä asioita asiakkaat ottavat puhelimitse yhteyttä eri paikkoihin sairaalassa, ja puhelut ohjautuvat vaihtelevasti myös lähi-, keski- ja ylimmälle johdolle. Suullisesti saatu asiakaspalautetieto on tärkeä etenkin lähijohtajille, mutta näin saatua asiakaspalautetietoa ei sairaalassa tallenneta systemaattisesti käytössä olevaan sähköiseen asiakaspalautejärjestelmään.

Lähijohto, ryhmä I: Edelleen jotkut, sanotaan nyt vanhempi väestö ei halua antaa huonoa palautetta, koska he edelleenkin niinkun ajattelee, että se vaikuttaa siihen hoitoon ja myös omaisilla on vähän samanlainen ajattelu. Siinä on myös semmonen haaste, millä me saadaan potilaat luottamaan siihen, että me halutaan vaan sitä toimintaa kehittää ja on tosi tärkeätä sanoo kaikki, mitä on siihen hoitoon liittyvää.

Asiakkailta kirjeitse saatavien palautteiden määrä on vähentynyt sairaalassa ratkaisevasti samalla, kun sähköpostilla tulevat palautteet ja tiedustelut ovat yleistyneet. Kirjallista asiakaspalautetietoa saadaan pääasiassa sairaalassa käytössä olevan sähköisen asiakaspalautejärjestelmän kautta. Asiakaspalautetta kerätään erillisellä palautelomakkeella. Palautelomakkeelta tiedot kirjataan sähköiseen asiakaspalautejärjestelmään, joka työllistää lähijohtajina toimivia osastonhoitajia kaikissa työyksiköissä. Haastateltavat toivat esille, että palautelomaketta ei tarjota systemaattisesti kaikille asiakkaille, ja palautemäärät jäävät osittain tästä syystä melko pieniksi. Asiakkaat ja heidän omaisensa pystyvät antamaan palautetta myös organisaation verkkosivujen kautta, mutta tätä mahdollisuutta on käytetty vähän.

Sairaalassa käytössä olleiden erilaisten palautekyselykokeiluiden avulla on saatu täsmällisempää palautetietoa pieniltä asiakasryhmiltä. Ajoittain on toteutettu lisäksi asiakaspalautteiden tehostettuja keräyksiä, mutta näiden tu- lokset ovat jääneet vaatimattomiksi. Joillekin asiakkaille on voitu tarjota käyttöliittymä, joka on mahdollistanut asiakkaan itsensä tekemät omaa vointiaan ja hoidon vaikuttavuutta koskevat kirjaukset tietojärjestelmään joko kotona tai sairaalassa ennen lääkärin vastaanottoa. Haastateltavat nostivat keskusteluun erilaisten asiakkaiden, kuten lasten ja heidän perheidensä, ikääntyneiden ja vakavasti sairastuneiden asiakkaiden mahdollisuudet antaa palautetta. Uusien palautekanavien, kuten tekstiviestipalauteen suunnittelussa pidettiin tärkeänä palautteen antamisen helppoutta, asiakkaiden tasavertaisia mahdollisuuksia antaa palautetta ja asiakaspalautetiedon käsittelyn sujuvuutta. Tietoteknisten ratkaisujen tulisi tukea toimintaa ja johtamistyötä. Haastattelut osoittivat, että sosiaalisen median kasvava merkitys asiakaspalautetiedon välittäjänä tunnistettiin, mutta organisaatiossa ei vielä ole yhteistä näkemystä siitä, miten sairaala voi hyödyntää sosiaalista mediaa asiakaspalautekanavana. Digitalisaation nähtiin mahdollistavan aikaisempaa monimuotoisempien palautekanavien käyttöön ottamisen sairaalassa.

Ylin johto, ryhmä I: Tavallaan taas tää digitalisaatiomaailma on varmaan tunnistettu, että ketteryyttä tarvitaan myös tässä asiassa ja ollaan otettu käyttöön näitä nopeita palautekanavia, jotka ikään kuin vois antaa meille määrällisesti sellaista ketteryyttä siinä tiedon saamisessa asiakkailta ja toisaalta vähentää sitä prosessiin käytettävää aikaa.

Asiakasraadin ja kokemusasiantuntijoiden merkitys edustuksellisen asiakaspalautetiedon antajina nousi keskusteluun molemmissa fokusryhmissä. Johtajat kokivat nämä uudet toimintamuodot vielä jäsentymättömiksi ja pääasiassa yksittäisten kysymysten äärellä oleviksi. Potilasasiamiesten asiakkaiden yhteydenottojen perusteella kokoamalla asiakaspalautetiedolla nähtiin sitä vastoin olevan vakiintunut rooli sairaalassa. Asiakkaiden tekemien muistutusten, kanteluiden ja potilasvahinkoilmoitusten käsittelystä sairaalassa on oma ohjeistuksensa. Haastateltavat pitivät henkilökunnan johdolle kertomaa tietoa arjen tapahtumista arvokkaana. Sitä täydentävät johtajien itsensä tekemät havainnot työyksiköiden toiminnasta ja saatu sanaton viestintä. 


\section{Asiakaspalautetiedon sisältö sairaalassa}

Sairaalassa saatu asiakaspalautetieto jakaantuu palvelua, hoitoa, asiakkaan kohtelua ja sairaalan toimintaa koskevaan tietoon. Palvelua koskeva tieto muodostuu monista erilaisista tekijöistä ja pitää sisällään asiakkaiden arvion palvelun saatavuudesta, sisällöstä ja sujuvuudesta. Hoitoon liittyvissä palautteissa nousevat esille moninaiset arkipäivän hoitamiseen ja turvallisuuteen liittyvät asiat sekä tiedonkulku. Asiakkaat kiinnittävät huomiota myös tietosuojan toimivuuteen tai siihen liittyviin epäkohtiin, joista sairaalassa saadaan yksittäisiä palautteita. Haastateltavat arvioivat, että varsinaisia hoidon sisältöön tai hoitomenetelmiin kohdistuvia palautteita asiakkailta tulee vähän. Kohtelua koskeva asiakaspalautetieto muodostuu asiakkaiden, omaisten ja ammattihenkilöiden kohtaamisista erilaisissa palvelu- ja hoitotilanteissa. Kohteluun liittyvää asiakaspalautetta sairaalassa saadaan jatkuvasti. Siihen liittyy usein asiakkaan tarve purkaa eri syistä syntynyttä mielipahaa ja keskustella omasta kokemuksestaan työntekijöiden kanssa.

Keskijohto, ryhmä II: ...miten asiakas kokee saavansa sitä palvelua. Eli tavallaan se saavutettavuus ja se prosessi, miten se on toiminut... ja sit siinä on tämä ikään kuin kokemus tiedonsaannin ymmärrettävyydestä. Sitten siinä on asiakkaan kokemus siitä omasta osallisuudesta päätöksenteossa. Ja sit siinä on vielä ikään kuin se kokemus siitä, että miten turvallista se hoito on ollut. Ja sitten ihan keskeinen tää kohtelu.

Haastateltavien näkemyksen mukaan sairaalan toimintaan kohdistuvassa asiakaspalautteessa nousee esille erilaisia sairaalarakennuksiin, sairaalaympäristöön ja sairaalan toimivuuteen liittyviä asioita. Asiakkaat kiinnittävät huomiota opasteisiin, liikkumisen helppouteen, turvallisuuteen, yleisten tilojen siisteyteen ja viihtyisyyteen. Näiden havaintojen perusteella asiakkaat muodostavat kokonaiskuvan sairaalasta. Kansalaisilta eri tilanteissa saatava yleinen palaute kuvastaa puolestaan väestön käsitystä sairaalasta ja sen toiminnan luotettavuudesta. Hankalimpina haastateltavat pitivät tilanteita, joissa asiakkaan huomio sairaalan toimintaan liittyvästä asiasta on merkittävä, mutta yksittäisen johtajan mahdollisuudet korjata asia ovat olemattomat.

Haastateltavat kuvasivat sähköisen asiakaspalautejärjestelmän kautta saatavaa asiakaspalautetietoa pääasiassa positiiviseksi. Se sisältää runsaasti kiittävää palautetta hoidosta, ystävällisestä kohtelusta ja sairaalan toiminnasta. Kiittävää palautetta saadaan asiakkailta myös henkilökohtaisesti eri ammattihenkilöille osoitettuna. Asiakkaiden tyytyväisyyteen vaikuttaa sairauden paraneminen tai ainakin hoidon eteneminen toivotulla tavalla. Asiakkailta saatava negatiivinen palaute liittyy tavallisesti hoito- ja toimintakäytäntöihin tai yksittäisen ammattihenkilön toimintaan, jolloin asiakkaan ja työntekijän kohtaaminen ei ole onnistunut asiakkaan odottamalla tavalla. Raskaimpina haastateltavat pitivät palveluun ja hoitoon tyytymättömien asiakkaiden tekemien muistutusten ja kanteluiden käsittelyä. Asiakaspalautetieto sisältää myös neutraaleja toimintaan liittyviä huomioita tai parannusehdotuksia.

\section{Asiakaspalautetiedon käsittely ja jakaminen sairaalassa}

Asiakaspalautetietoa käsitellään ja jaetaan sairaalassa ensisijaisesti työyksiköissä, joissa tiedon käsittely ja jakaminen tapahtuvat pääasiassa hoitotyön lähijohtajana toimivan osastonhoitajan hoitohenkilökunnan kanssa pitämissä osastokokouksissa. Näihin kokouksiin lääkärit osallistuvat harvoin, mutta erilaisissa hoitotiimeissä asiakkailta saatavaa tietoa käsitellään yhdessä eri ammattiryhmien kesken. Asiakkaiden tekemiin muistutuksiin ja kanteluihin vastattaessa tarvitaan eri ammattiryhmiin kuuluvien henkilöiden näkemyksiä. Näissä tilanteissa syntyy myös laajempaa moniammatillista keskustelua asiakkaan kokemuksesta. Saadut asiakaspalautteet pyritään käsittelemään työyksikössä nopeasti. Osastonhoitaja vastaa työyksikössä asiakaspalautetiedon perusteella tarvittavista kehittämistoimenpiteistä, joiden toteuttaminen ja seuranta jäävät usein osastonhoitajalle. Lähijohtajana toimiva lääkäri ja osastonhoitaja siirtävät työyksiköistä asiakaspalautetietoa seuraavalle johtamisen tasolle. Sairaalassa tieto välittyy johtamistasolta toiselle ensisijaisesti omaa am- 
mattiryhmää edustavan johtajan kautta, vaikka moniammatillistakin keskustelua käydään. Haastateltavat kokivat, että asiakkailta saatavan tiedon siirtämistä johtamistasolta toiselle vaikeuttaa organisaatiossa laadittujen ohjeiden vaihteleva tulkinta. Näkemykset siitä, mitä ja millä tavalla asiakaspalautetietoa eri johtamistasojen välillä jaetaan, eivät ole yhtenäisiä.

Keskijohto, ryhmä I: Jotkut lähiesimiehet kokevat, että he eivät halua häiritä ylempää tahoa, hoitavat itse ja asioita jää hoitamatta, jotkut taas laittavat kaiken ylemmälle taholle.

Asiakaspalautetieto ja potilasasiamiesten asiakkaiden yhteydenottojen perusteella tuottama tieto käsitellään johtoryhmissä kaikilla johtamisen tasoilla, mutta käsittelykäytännöt vaihtelevat sairaalan eri alueilla ja johtamistasolta toiselle siirryttäessä. Asiakaspalautetiedon käsittely sairaalassa näyttäytyy ensisijaisesti toteavana. Keskijohdossa ja ylimmässä johdossa asiakaspalautetieto muuttuu tilastoiksi, ja sen yhteys työyksikköihin heikkenee. Eri alueilta sairaalasta saatu asiakaspalautetieto käsitellään myös ylimmän johdon johtoryhmässä. Tämän käsittelyn perusteella ylimmässä johdossa on pystytty nostamaan esille sairaalan yhteisiä asiakaslähtöisyyttä painottavia kehittämiskohteita, kuten asiakkaan kohtelu, ohjaus ja omaisten huomioiminen. Haastatteluihin osallistuneet johtajat toivat esille, että johtamisen eri tasoilla sairaalassa ei voida yksin miettiä asiakaspalautetiedon käsittelyprosessin toimivuutta tai tehdä siihen tarvittavia muutoksia laajemmin. Haastateltavien näkemyksen mukaan tiedon hyödyntäminen ja tarvittavien muutosten toteuttaminen onnistuvat parhaiten työyksiköissä, kuten poliklinikoillaja vuodeosastoilla. Asiakaspalautetiedon siirtämistä alemmalta johtamistasolta seuraavalle tasolle hankaloittaa ylemmältä johtamistasolta saatavan palautteen niukkuus. Yhteisistä kokouskäytännöistä huolimatta asiakaspalautetiedon käsittelyssä ja jakamisessa huomio kiinnittyy lääkäreiden ja hoitohenkilökunnan toiminnan eriytyneisyyteen sairaalassa. Yhteiseltä asiakkaalta saadun asiakaspalautetiedon käsittely ja välittäminen johtamistasolta toiselle tapahtuu ensisijaisesti ammattiryhmäkohtaisissa sosiaalisissa vuorovaikutustilanteissa. Asiakaspalautetiedon jakaminen sairaalassa horisontaa- lisesti eri alueille on vähäistä.

Lähijohto, ryhmä I: Monessa muussakin asiassa kuin näissä palauteasioissa meidän klinikka toimii niinkun silleen, että on hirveen erikseen se hoitotyö ja lääkärit erikseen. Jos se on joku tällanen pieni juttu, niin se on niinkun osastonhoitajan ja mun välinen juttu. Jos se antaa aihetta, niin osastonhoitaja vie sen hoitajakuntaan ja minä vien sen lääkärikuntaan. Ja sitten niistä semmoisista vähän laajemmista ja virallisemmista on sitten johtoryhmässä, missä keskustellaan. Osastonhoitajat vie tietty sitten tiedon ylihoitajalle ja minä taas toimialuejohtajalle.

\section{Asiakaspalautetiedon hyödyntäminen johtamisessa}

Haastateltavien johtajien käsityksen mukaan asiakaspalautetietoa arvostetaan sairaalassa. Se ohjaa johtamista ja auttaa johtajaa kiinnittämään huomiota asiakkaiden esille nostamiin asioihin. Johtajat kertoivat pyrkivänsä hyödyntämään asiakaspalautetietoa aktiivisesti omassa johtamistyössään. Keskeisinä tavoitteina pidettiin oman alueen toiminnan kehittämistä, asiakaspalvelun parantamista ja asiakaslähtöisyyden edistämistä. Eri ammattihenkilöille suunnattua positiivista henkilökohtaista palautetta saadaan työyksiköissä usein ja siitä kerrotaan mielellään henkilökohtaisesti työntekijälle sekä koko työyhteisölle. Positiivisen palautteen nähtiin tukevan työssä jaksamista, ja sillä on suuri merkitys työhyvinvoinnin edistämisessä koko työyhteisössä.

Johtajat pitivät raskaana asiakkaiden esille nostaman epäasiallista kohtelua koskevan palautteen käsittelyä työyhteisössä. Valittavat johtamistoimet näissä tilanteissa riippuvat aina tilanteen vakavuudesta ja saadun palautteen sisällöstä. Negatiivinen yksilöity asiakkaalta saatu palaute käsitellään lähijohtajan ja työntekijän välisessä keskustelussa. Asiakkaan epäasialliseen kohteluun puuttuminen haastaa koko johtamisketjun, jonka tulisi toimia yhtenäisen näkemyksen mukaisesti. Asiakaspalautetiedon perusteella toteutetuksi konkreettiseksi kehittämishankkeeksi haastateltavat nimesivät organisaatiossa toteutetun asiakaskokemuksen kehittämisohjelman, johon sisältyy asiakaslähtöisyyden edistäminen ja asiakkaan osallistumisen vahvistaminen omassa hoidossaan. 
Keskijohto, ryhmä II: Kyllä se, että voi puuttua tämmöseen epäasialliseen kohteluun, niin kyllä se usein tarkoittaa sitä, että se koko johtamisketju täytyy olla hyvin yhteneväinen, että siellä ei voi olla tavallaan sellasta, että käsitykset ei voi olla erilasia johtamisen eri foorumeilla.

Asiakkailta saatava tieto auttaa johtajia tunnistamaan osaamisvajeita, joihin koulutuksen keinoin voidaan puuttua. Tähän sairaalassa on reagoitu tarjoamalla henkilökunnalle esimerkiksi ohjaukseen ja asiakkaiden kohtaamiseen liittyvää koulutusta. Haastateltavien näkemyksen mukaan sairaanhoidon osaaminen on sairaalassa hyvällä tasolla, mutta puutteita on erityisesti asiakaspalveluosaamisessa. Asiakaspalautetietoa pystytään hyödyntämään parhaiten työyksiköiden toiminnan ja osaamisen kehittämisessä.

\section{Yhteinen organisatorinen asiakaspalautetieto}

Johtajien näkemysten mukaan asiakaspalautetietoa kootaan sairaalassa eri tavoin, käsitellään johtamisen eri tasoilla ja siirretään johtamistasolta toiselle johtajien ja työntekijöiden välisessä vuorovaikutuksessa. Tätä kautta muodostuva yhteinen organisatorinen näkemys asiakaspalautetiedon kokonaisuudesta jää kuitenkin heikoksi. Sairaalassa ei ole yhtenäistä näkemystä siitä, millä tavalla asiakaspalautetieto läpäisee koko organisaation. Käsitykset siitä, miten eri työyksiköistä tulevaa asiakaspalautetietoa käsitellään ja analysoidaan johtamisen eri tasoilla ja siirretään johtamistasojen välillä, ovat erilaisia sairaalan eri alueilla. Siitä, miten koko sairaalaa koskeva asiakaspalautetieto kootaan yhteen, ei haastateltavilla ollut näkemystä. Ylimmän johdon käsittelyn jälkeen asiakaspalautetieto raportoidaan vuosikertomuksessa. Se, mitä tiedolle tämän jälkeen tapahtuu, jää alemmilla johtamisen tasoilla epäselväksi. Osa haastatteluun osallistuneista johtajista toi esille, että eri tavoin kootun asiakaspalautetiedon tulisi olla yhdistettävässä muodossa. Tiedon tulisi kumuloitua ja palautua johtajien käyttöön hyödynnettäväksi kaikilla johtamisen tasoilla, jotta sen avulla voi- taisiin kehittää systemaattisesti henkilökunnan osaamista, asiakkaille tarjottavaa palvelua ja hoitoa sekä organisaation toimintaa. Haastateltavat arvioivat asiakaslähtöisyyden ja asiakaspalautetiedon merkityksen kasvavan tulevaisuudessa ja linkittyvän yhä keskeisemmin osaksi sairaalan johtamisessa tarvittavaa tietoa.

Ylin johto, ryhmä I: Asiakastieto johtamisen tietona, miten tieto läpäisee koko organisaation. Asia ei ole vielä hallinnassa ja työtä on paljon edessä, jotta asiakastieto saadaan näyttäytymään kokonaisvaltasesti osana johtamisen tietoa.

\section{POHDINTA JA JOHTOPÄÄTÖKSET}

\section{Tutkimustulosten tarkastelu}

Tutkimuksessa tarkasteltiin asiakaspalautetiedon hyödyntämistä sairaalan johtamisessa organisaation eri tasoilla toimivien johtajien kuvaamana. Asiakaslähtöisyyttä pidetään keskeisenä arvona sairaalan toiminnassa ja asiakaspalautetietoa kootaan sairaalassa useasta eri lähteestä samanaikaisesti. Asiakkaat antavat palautetta ensisijaisesti konkreettisista palveluun, hoitoon ja kohteluun liittyvistä asioista (Woodside ym. 1989; Ramsaran-Fowdar 2005), joissa onnistuminen herättää asiakkaissa luottamusta. Asiakaspalautetiedon hallinnan kokonaisuutta ei ole mietitty ja suunniteltu sairaalassa riittävästi. Tutkimus osoitti, että kirjallisen asiakaspalautetiedon kokoaminen eri lähteistä on sairaalassa vakiintunutta. Asiakkaiden suullisesti antamaa palautetta ei kerätä ja yhdistetä muulla tavoin koottuun asiakaspalautetietoon. Suullisen asiakaspalautteen systemaattinen kokoaminen nostaisi kuitenkin sairaalassa kerättävän asiakaspalautetiedon arvoa (Garcia-Murillo \& Annabi 2002; Kaseva 2011). Tiedonhallinnan kokonaisuuden suunnittelussa olennaista on käytettävien tietolähteiden valinta, tiedon käsittelystä ja jakamisesta sopiminen sekä tiedon tarkastelun ja hyödyntämisen miettiminen (ks. Choo 1996). Näiden vaiheiden suunnittelu ei voi olla organisaatiossa satunnaista. Organisaatiossa tulisi muodostua kokonaiskuva asiakaspalautetiedosta ja sen hyödyntämisestä. Nykyisellään asiakaspalautetiedon hyödyntäminen sairaalan 
johtamisessa näyttäytyy satunnaisena, koska eri lähteistä saatavaa tietoa on vaikea yhdistää osaksi johtamistietoa.

Johtajat tunnistivat hyvin aikaisemmissa tutkimuksissa (esim. Mulcahy 2003; KalliomaaPuha 2015) esille nostetut asiakaspalautteen antamiseen liittyvät jännitteet sairaalassa. Asiakkaan rooliin perinteisenä potilaana ei edelleenkään kuulu palvelun ja hoidon arvioiminen tai negatiivisen palautteen antaminen. Ammattihenkilöillä on lisäksi omat odotuksensa asiakkaiden suhtautumisesta toteutettavaan hoitoon. Mikäli asiakaspalautetiedon keräämisen lähtökohta on vahvasti organisatorinen, asiakkaille esitetyillä kysymyksillä ei välttämättä saada riittävästi tietoa asiakkaille merkityksellisistä asioista. Valtakunnalliset linjaukset asiakaslähtöisten palvelujen toteuttamisesta tukevat systemaattisen asiakaspalautetiedon keräämistä sairaalassa (Sihvo ym. 2018), mutta valtakunnallisen vertailutiedon vajavaisuus heikentää osaltaan yksittäisen sairaalan motivaatiota asiakaspalautetiedon hallinnan ja hyödyntämisen parantamiseen.

Tämä tutkimus osoitti, että lääkärit ja hoitohenkilökunta jakavat asiakaspalautetietoa pääasiassa omaa ammattiryhmää edustavan johtajan kautta (ks. Kivinen 2008; Currie \& White 2012; Tasseli 2014). Sairaalassa vallitsevat vahvat ammattiryhmäkohtaiset alakulttuurit ja ammattiryhmien väliset raja-aidat ovat nähtävissä asiakaspalautetiedon käsittelyssä. Tiedonkulku ei ole riittävää eri ammattiryhmien ja johtamistasojen välillä. Sairaaloiden rakenteita ja johtamisjärjestelmiä on uudistettu prosessiorganisaatioiden suuntaan. Kehityksestä huolimatta lääketieteen erikoisalojen ja yksiköiden autonomia näyttäytyy vahvana hidastaen yhtenäisten toimintamallien luomista. Tutkimustulokset toivat esille sairaalassa vallitsevat vaihtelevat näkemykset siitä, millä tavalla asiakaspalautetietoa tulisi jakaa eri johtamistasojen välillä. Sairaalan tämän hetkiset toimintakäytännöt eivät edistä SECI-mallin mukaisen uuden tiedon syntymistä organisaatiossa (Nonaka \& Takeuchi 1995). Asiakaspalautetiedon käsittely aidosti moniammatillisessa yhteistyössä tukisi kuitenkin asiakaspalautetiedon hallinnan suunnittelua ja yhteisen organisatorisen näkemyksen muodostumista.

Eri tasoilla toimivien johtajien näkemys asiakaslähtöisyydestä on yhtenäinen. Asiakaslähtöi- syys näyttäytyy sairaalan toiminnassa keskeisenä arvona, joten sairaalassa toimivat johtajat eivät mielellään tuo esille mahdollisia eriäviä näkemyksiä asiakaslähtöisyydestä (ks. Epstein ym. 2010; Santana ym. 2018). Asiakaslähtöisyyttä koskeva argumentointi ja asiakaslähtöisyyden todellinen toteutuminen asiakkaan palvelu- ja hoitokontakteissa ovat kuitenkin erillisiä asioita. Johtajat tunnistavat hyvin johtamisrooliin liittyvät vastuut niissä tilanteissa, joissa esimerkiksi asiakkaaseen kohdistuvaan epäasialliseen kohteluun joudutaan puuttumaan. Johtajat ovat tietoisia asiakaspalautetiedon sisällöstä, mutta tiedon perusteella toteutettava johtamistyö ja kehittämistoimenpiteet ovat rajallisia. Yksittäisten johtajien mahdollisuudet edistää asioita sairaalassa ovat tarkasti johtamisaseman perusteella määriteltyjä.

Suomessa julkisella sairaalaorganisaatiolla on vakiintunut tehtäväalue, eikä sen ole monopolina tarvinnut juurikaan kilpailla asiakkaista. Näin ollen asiakaspalautetiedolla ei julkisessa sairaalassa ole samanlaista merkitystä kuin yksityisessä sairaalassa. Saadulla asiakaspalautetiedolla on kuitenkin julkisessa terveydenhuollossa tunnustettu eettiseen arvopohjaan perustuva rooli. Nykyisin luottamushenkilöiden, poliittisten päättäjien ja asiakkaiden itsensä saama tieto asiakaspalautteesta ja sen hyödyntämisestä sairaalassa on vähäistä. Asiakaspalautetieto ei välity laajemmin väestölle, joten sen merkitys organisaation imagon rakentamisessa jää vähäiseksi. Sairaalan toiminnan kehittäminen asiakkaiden tarpeet huomioiden edellyttää asiakaspalautetiedon systemaattisempaa hyödyntämistä. Tämä vaatii tiedonhallinnan prosessin kriittistä tarkastelua, uuden organisatorisen tiedon muodostamisen käytäntöjen yhtenäistämistä ja uusien johtamiskäytäntöjen luomista. Choon (1996, 2002) esittämä näkemys tiedon muodostumisesta jatkuvana syklinä soveltuu hyvin asiakaspalautetiedon hyödyntämisen tarkasteluun sairaalan johtamisessa. Tutkitussa sairaalassa asiakaspalautetiedon hallinnan prosessi ei nykyisellään kanna niin pitkälle, että kattavaa yhteistä organisatorista asiakaspalautetietoa pystyttäisiin muodostamaan ja hyödyntämään koko organisaatiossa (ks. Nonaka \& Takeuchi 1995; Choo 1996, 2002). 


\section{Tutkimuksen eettiset lähtökohdat ja luotettavuus}

Tässä tutkimuksessa kiinnitettiin erityistä huomiota jokaisen tutkimukseen osallistuvan anonymiteetin turvaamiseen (Kylmä \& Juvakka 2007). Tästä syystä tutkimukseen osallistuneiden henkilöiden taustatietoja ja organisaatioon liittyviä tietoja on kuvattu niukasti. Tutkimustuloksissa esitetyt suora lainaukset on tarkistettu siltä osin, että yksittäiset henkilöt tai organisaatio eivät ole niistä tunnistettavissa. Tutkijan vuorovaikutus tutkittavan organisaation kanssa ja organisaation toiminnan tuntemus on edistänyt tutkimuksen toteuttamista. Tähän liittyvä tutkijan position vaikutus tutkimuksen luotettavuuteen, on pyritty tiedostamaan koko tutkimusprosessin ajan. Kaikkien tutkimukseen osallistuneiden näkemyksiä on pidetty tasavertaisina ja ne on pyritty raportoimaan mahdollisimman rehellisesti. Tutkimukseen osallistujat valittiin johtamisposition perusteella siten, että he edustivat laajasti sairaalan erilaisia alueita ja siten erilaisia asiakkaita sekä olivat halukkaita kertomaan näkemyksistään. (Eskola \& Suoranta 1998.) Aineistonkeruumenetelmänä käytettiin fokusryhmähaastattelua, joka on aina luonteeltaan ainutkertainen. Molemmissa fokusryhmähaastatteluissa haastateltavat uskalsivat tuoda avoimesti esille näkemyksiään. Sama tutkija haastatteli, litteroi ja analysoi aineiston, mitä pidetään tärkeänä tulosten uskottavuuden näkökulmasta. (Kylmä \& Juvakka 2007; Krueger \& Casey 2009.) Tutkimustulokset on raportoitu tutkimuskysymysten mukaisesti. Suorien lainausten avulla lukijan on mahdollista arvioida tutkijan tekemien päätelmien luotettavuutta. Tulkintojen oikeellisuuden varmistamiseksi tutkija kävi haastattelu-

\section{LÄHTEET}

Angstman, Kurt B., Bender, Robert O. \& Bruce, Steven M. (2009). Patient Advisory Groups in Practice Improvement: Sample Case Presentation With a Discussion of Best Practices. Journal of Ambulatory Care Management, 32(4), 328-332.

Arantola, Heli (2006). Customer insight: Uusi väline liiketoiminnan kehittämiseen. Helsinki: WSOYpro Oy. aineiston ja analysointivaiheessa saadut tulokset läpi useaan kertaan.

\section{Johtopäätökset}

Koska tutkimus on luonteeltaan tapaustutkimus ja kohdistui ainoastaan yhteen julkiseen sairaalaan, on syytä pohtia tutkimustulosten hyödynnettävyyttä muissa terveydenhuollon organisaatioissa. Voidaan kuitenkin olettaa, että asiakaspalautetiedon johtamiseen liittyvät kysymykset ovat samansuuntaisia julkisissa suomalaisissa sairaaloissa. Asiakaspalautetiedon hyödyntäminen johtamisessa edellyttää yhteistä keskustelua koko tiedonhallinnan prosessista, sopimista yhtenäisistä toimintatavoista ja toimivien johtamiskäytäntöjen kehittämistä. Asiakaspalautetiedon merkitys nousee esille organisaation eri tasoilla toimivien johtajien puheessa, mutta sairaalan toimintamallit eivät tue aidosti asiakaspalautetiedon käyttöä johtamisessa ja kehittämisessä. Terveydenhuollossa tulevaisuudessa toteutettavat muutokset saattavat synnyttää julkisissa sairaaloissa kilpailua, joka pakottaa miettimään asiakaspalautetiedon käyttöä uudella tavalla. Nykyiset asiakaspalautetiedon hallinnan käytännöt eivät ole riittäviä tulevaisuuden sairaalassa. Tutkimus nosti esille sairaalan asiakaspalautetiedon johtamiseen liittyvät haasteet, jotka antavat aihetta terveydenhuollon tiedonhallinnan prosessien johtamisen laajempaan tutkimiseen jatkossa. Tutkimustulokset osoittivat, että vaikka asiakaslähtöisyys on terveydenhuollossa tunnustettu toiminnan lähtökohta ja johtajat laajasti jakavat myös tämän, sairaalan toimintamallit eivät mahdollista asiakastiedon täysimääräistä hyödyntämistä osana johtamisen tietoperustaa.

Bleich, Sara, Özaltin, Emre \& Murray, Christopher (2009). How does satisfaction with health-care system relate to patient experience? Bulletin of the World Health Organization, 87(4), 271-278.

Bouthillier, France \& Shearer, Kathleen (2002). Understanding knowledge management and information management: the need for an empirical perspective. Information Research, 8(1), 1-23. Haettu sivulta http://www.informationr. net/ir/8-1/paper141.html, 10.6.2018. 
Butler, Daniel, Oswald, Sharon L. \& Turner, Douglas E. (1996). The effects of demographics on determinants of perceived health-care service quality: The case of users and observers. Journal of Management in Medicine,10(5), 8-20.

Chen, Injazz J. \& Popovich, Karen (2003). Understanding customer relationship management (CRM). People, process and technology. Business Process Management Journal, 9(5), 672-688.

Chen, Yung-Hsin \& Su, Chao-Ton (2006). A Kano-CKM Model for Customer Knowledge Discovery. Total Quality Management, 17(5), 589-608.

Choo, Chun Wei (1996). The Knowing Organization: How Organizations Use Information to Construct Meaning, Create Knowledge and Make Decisions. International Journal of Information Management, 16(5), 329-340.

Choo, Chun Wei (2002). Information Management for the Intelligent Organization. The Art of Scanning the Environment (3th ed.). American Society for Information Science and Technology. Medford, New Jersey: Information Today Inc.

Currie, Graeme \& White, Leroy (2012). Interprofessional Barriers and Knowledge Brokering in an Organizational Context: The Case of Healthcare. Organization Studies, 33(10), 13331361.

Davenport, Thomas \& Prusak, Laurence (1998). Working Knowledge. How Organizations Manage What they know. Boston: Harvard Business School Press.

Deber, Raisa B., Kraetschmer, Nancy, Urowitz, Sara \& Sharpe, Natasha (2005). Patient, consumer, client or customer: what do people want to be called? Health Expectations, 8, 345-351.

Easton, Geoff (1992). Learning from case studies (2nd ed.). Great Britain: BPCC Wheatons Ltd, Exeter.

Edwards, Carol, Stanizweska, Sophie \& Crichton, Nicola (2004). Investigation of the ways in which patients' reports of their satisfaction with healthcare are constructed. Sociology of Health \& Illness, 26(2), 159-183.

Epstein, Ronald M., Fiscella, Kevin, Lesser, Cara S. \& Stange, Kurt C. (2010). Why The Nation Needs A Policy Push On Patient-Centered Health Care. Health Affairs, 29(8), 1489-1495. Haettu sivulta https://www.healthaffairs.org/ doi/10.1377/hlthaff.2009.0888, 10.7.2018.

Eskola, Jari \& Suoranta, Juha (1998). Johdatus laadulliseen tutkimukseen. Tampere: Vastapaino.

García-Murillo, Martha \& Annabi, Hala (2002). Customer knowledge management. Journal of the Operational Research Society, 53(8), 875884.

Hakulinen, Hanna, Lammintakanen, Johanna \& Rissanen, Sari (2012). Terveydenhuollon muutostutkimus 2000-2010 - kirjallisuuskatsaus. Hallinnon tutkimus, 31(1), 19-35.

Harrison, Reema, Walton, Merrilyn, Healy, Judith, Smith-Merry, Jennifer \& Hobbs, Coletta (2016). Patient complaints about hospital services: applying a complaint taxonomy to analyse and respond to complaints. International Journal for Quality in Health Care, 28(2), 240-245.

Hirsjärvi, Sirkka, Remes, Pirkko \& Sajavaara, Paula (2008). Tutki ja kirjoita. Keuruu: Otavan Kirjapaino Oy.

Johansson, Peter, Olén, Magnus \& Frilund, Bengt (2002). Patient satisfaction with nursing care in the context of health care: a literature study. Scandinavian Journal of Caring Science, 16, 337-344.

Jylhä, Virpi (2017). Information Management in Health Care. A model for connecting information culture and patient safety. Dissertations in Social Sciences and Business Studies No 140. Kuopio: University of Eastern Finland.

Kakabadse, Nada K., Kouzmin, Alexander \& Kakabadse, Andrew (2001). From Tacit Knowledge to Knowledge Management: Leveraging Invisible Assets. Knowledge and Process Management, 8(3), 137-154.

Kalliomaa-Puha, Laura (2015). Potilaasta aktiiviseksi ja autonomiseksi kuluttajaksi? Teoksessa Niemelä, Mikko, Kokkinen, Lauri, Pulkki, Jutta, Saarinen, Arttu \& Tynkkynen, Liina-Kaisa (toim.), Terveydenhuollon muutokset: Politiikka, järjestelmä ja seuraukset (s. 133-153). Tampere: Tampere University Press.

Kaseva, Kaisa (2011). Asiakkaan asema, itsemäärääminen ja vaikutusmahdollisuudet sosiaali- ja terveydenhuollon kehittämisessä - Integroitu kirjallisuuskatsaus. Sosiaali- ja terveysministeriön raportteja ja muistioita. Helsinki: Sosiaali- ja terveysministeriö. Haettu sivulta http://urn.fi/ URN:ISBN:978-952-00-3188-6, 25.5.2018.

Kim, Yong-Mi, Newby-Bennett, Donna \& Song, Hee-Joon (2012). Knowledge sharing and institutionalism in the healthcare industry. Journal of Knowledge Management, 16(3), 480-494.

Kivinen, Tuula (2008). Tiedon ja osaamisen johtaminen terveydenhuollon organisaatiossa. Kuopion yliopiston julkaisuja E. Yhteiskuntatieteet 158. Kuopion yliopisto.

Krueger, Richard A. \& Casey, Mary Anne (2009). Focus Groups: A Practical Guide for Applied Research. Thousand Oaks, California: Sage Publications. 
Kumah, Emmanuel, Ankomah, Samuel E. \& Kesse, Felix O. (2018). The Impact of patient feedback on clinical practice. British Journal of Hospital Medicine, 79(12), 700-703.

Kylmä, Jari \& Juvakka, Taru (2007). Laadullinen terveystutkimus. Helsinki: Edita.

Latvala, Eila \& Vanhanen-Nuutinen, Liisa (2001). Laadullisen hoitotieteellisen tutkimuksen perusprosessi: Sisällönanalyysi. Teoksessa Janhonen, Sirpa \& Nikkonen, Merja (toim.), Laadulliset tutkimusmenetelmät hoitotieteessä (s. 21-43). Juva: WS Bookwell Oy.

Mair, Frances \& Whitten, Pamela (2000). Systematic review of studies of patient satisfaction with telemedicine. British Medical Journal, 320(3), 1517-1520.

Mazurenko, Olena, Zemke, Dina M., Harrah, William F. \& Lefforge, Noelle (2016). Who Is a Hospital's "Customer"? Journal of Healthcare Management, 61(5), 319-333.

Mertala, Sirpa (2011). Yhdessä tietämisen episodeja - Terveydenhuollon kompleksiset työympäristöt. Lapin yliopisto. Yhteiskuntatieteellinen tiedekunta. Rovaniemi: Lapin yliopistokustannus.

Mulcahy, Linda (2003). Disputing Doctors: The sosio-legal Dynamics of Complaints about Medical Care. Berkshire: Open University Press.

Myllärniemi, Jussi, Laihonen, Harri, Karppinen, Henri \& Seppänen, Kaisa (2012). Knowledge management practices in healthcare services. Measuring Business Excellence, 16(4), 54-65.

Naidu, Aditi (2009). Factors affecting patient satisfaction and healthcare quality. International Journal of Health Care Quality Assurance, 22(4), 366-381.

Nonaka, Ikujiro \& Takeuchi, Hirotaka (1995). The Knowledge-Creating Company. How Japanese Companies Create the Dynamics of Innovation. Oxford: Oxford University Press.

Palomäki, Susanna \& Vanhala, Anni (2016). Terveydenhuollon muistutus asiakkaan arvioimana käytäntönä. Janus, 24(1), 45-61.

Peränen, Niina \& Sainio, Salla (2018). Asiakaspalautteen kansallisen keruun yhtenäistäminen - sisällölliset ehdotukset. Projektin loppuyhteenveto. Helsinki: Terveyden ja hyvinvoinnin laitos. Haettu sivulta http://www.julkari.fi/bitstream/ handle/10024/138460/20181022_asiakaspalautetiedonkeruu_yhteenveto_FINAL_korj20190130.pdf? sequence $=1$ \&isAllowed $=y$, 20.11.2018.

Pirttimäki, Virpi (2007). Business Intelligence as Managerial Tool in Large Finnish Companies. Tampere University of Technology. Publication 646. Haettu sivulta https://tutcris.tut.fi/portal/ files/1661109/pirttimaki.pdf, 20.1.2019.
Ramsaran-Fowdar, Roshnee R. (2005). Identifying health care attributes. Journal of Health and Human Services Administration, 27(4), 428-443.

Rissanen, Päivi \& Puumalainen, Jouni (2016). Kokemuksen kautta osaamiseen: vapaaehtoisuus, vertaisuus ja kokemusasiantuntijuus. Kuntoutus, $1,1-7$.

Santana, Maria J., Manalili, Kimberly, Jolley, Rachel J., Zelinsky, Sandra, Quan, Hude \& Lu, Mingshan (2018). How to practice person-centred care: A conceptual framework. Health Expectations, 21(2), 429-440.

Saranto, Kaija \& Kuusisto-Niemi, Sirpa (2011). Tiedon hallinta johtamisessa. Teoksessa Rissanen, Sari \& Lammintakanen, Johanna (toim.), Sosiaali- ja terveysjohtaminen (s. 215-236). Helsinki: WSOYpro Oy.

Sihvo, Sinikka, Isola, Anna-Maria, Kivipelto, Minna, Linnanmäki, Eila, Lyytikäinen, Merja \& Sainio, Salla (2018). Asiakkaiden osallistumisen toimintamalli. Loppuraportti. Sosiaali- ja terveysministeriön raportteja ja muistioita 16/ 2018. Helsinki: Sosiaali- ja terveysministeriö.

Sosiaali- ja terveysministeriö (2010). Sosiaalisesti kestävä Suomi 2020. Sosiaali- ja terveyspolitiikan strategia. Haettu sivulta https:// docplayer.fi/4646643-Sosiaalisesti-kestava-suomi-2020-sosiaali-ja-terveyspolitiikan-strategia. html, 30.6.2018.

Sosiaali- ja terveysministeriö (2014). Tieto hyvinvoinnin ja uudistuvien palvelujen tukena - Sote-tieto hyötykäyttöön -strategia 2020. Haettu sivulta

http://julkaisut.valtioneuvosto.fi/ bitstream/handle/10024/70321/URN_ ISBN_978-952-00-3548-8.pdf? sequence=1\&isAllowed=y, 29.6.2018.

Syväjärvi, Antti \& Pietiläinen, Ville (2016). Kohti inhimillistä ja tehokasta sosiaali- ja terveysalan organisaatioiden johtamista. Teoksessa Syväjärvi, Antti \& Pietiläinen, Ville (toim.), Inhimillinen ja tehokas sosiaali- ja terveysjohtaminen (s. 11-25). Tampere: Suomen Yliopistopaino Oy - Juvenes Print.

Taloney, Linda \& Flores, Gabriela (2013). Building Blocks for Successful Patient and Family Advisory Boards. Collaboration, Communication and Commitment. Nursing Administration Quarterly, 37(3), 247-253.

Tasseli, Stefano (2014). Social Networks of Professionals in Health Care Organizations: A Review. Medical Care Research and Review, 71(6), 619-660.

Terveyden ja hyvinvoinnin laitos (2011). Palautepalvelut. Esiselvitysraportti. SADe-ohjelma. Haettu sivulta 
https://www.thl.fi/documents/10531/105937/ Liite19_Palautepalvelut_esiselvitys.pdf, 22.9.2018.

Tritter, Jonathan (2009). Vallankumous vai hidas muutos - Miten ymmärtää kansalaisten ja potilaiden osallistumista? Teoksessa Koivusalo, Meri, Ollila, Eeva \& Alanko, Anna (toim.), Kansalaisesta kuluttajaksi. Markkinat ja muutos terveydenhuollossa (s. 210-226). Helsinki: Hakapaino Oy.

Tuomi, Jouni \& Sarajärvi, Anneli (2009). Laadullinen tutkimus ja sisällön analyysi. Helsinki: Tammi.

Valkama, Katja (2009). Muuttuneen asiakkuuden haaste sosiaali- ja terveydenhuollossa. Hallinnon tutkimus, 28(2), 26-40.

Valkonen, Marjo-Riitta, Kinnunen, Ulla-Mari \& Saranto, Kaija (2018). Tiedonhallinnan prosessimallin hyödyntäminen sosiaali- ja terveydenhuollon tiedonhallintaa koskevissa tutkimuksissa. Finnish Journal of eHealth and eWelfare, 10 (2-3), 285-296. Haettu sivulta https://erepo.uef.fi/bitstream/hand- le/123456789/6763/153381083031524187. pdf? sequence $=2$ \&isAllowed $=y$, 18.2.2019.

Valtioneuvoston kanslia (2015). Ratkaisujen Suomi. Pääministeri Juha Sipilän hallituksen strateginen ohjelma 29.5. Hallituksen julkaisusarja 10/2015. Helsinki: Edita Prima.

Virtanen, Petri, Suoheimo, Maria, Lamminmäki, Sara, Ahonen, Päivi \& Suokas, Markku (2011). Matkaopas asiakaslähtöisten sosiaali- ja terveyspalvelujen kehittämiseen. Tekes katsaus 281/2011. Helsinki: Tekes. Haettu sivulta https://www.businessfinland.fi/globalassets/ julkaisut/matkaopas.pdf, 20.9.2018.

White, Kristine (2012). Engaging patient to improve the healthcare experience. Healthcare Financial Management, 66(7), 84-88.

Woodside, Arch G., Frey, Lisa L. \& Daly, Robert T. (1989). Linking Service Quality, Customer Satisfaction, and Behavioral Intention. Journal of Health Care Marketing, 9(4), 5-17. 